\title{
Can the symptoms of schizophrenia be reset?
}

\author{
Czy można zresetować objawy schizofrenii?
}

Marcin Olajossy $_{A D E F}$, Ewelina Soroka $a_{B D E F}$

\author{
II Department of Psychiatry and Psychiatry Rehabilitation, Medical University of Lublin
}

\begin{abstract}
This work basing on a study of medical records is a story of a young patient, repeatedly hospitalized with various diagnose s, in whom the psychiatric symptoms significantly decreased after waking from coma, resulting from an unfortunate accident.

There are presented subsequent stages of treatment and hospitalizations and the analysis of the problem if the re-start is possible in terms of mental state, in a patient who for years had experienced omental-delusive experiences of high severity and anxiety, leading to several suicidal attempts with serious consequences.

The discussion also describes the issue of double diagnosis and the criteria for amphetamine-induced psychosis.

Can schizophrenia be cured and its symptoms reset?
\end{abstract}

Keywords: schizophrenia, amphetamine-induced psychosis, remission

\section{Streszczenie}

Niniejsza praca jest opartą na studium dokumentacji medycznej historią młodej pacjentki, wielokrotnie hospitalizowanej z różnymi rozpoznaniami, u której objawy psychiatryczne w sposób znaczący zmniejszyły się po wybudzeniu ze śpiączki, jaka była następstwem nieszczęśliwego wypadku.

Przedstawiono tu kolejne etapy leczenia i hospitalizacje a także poddano analizie problem, czy jest możliwy powtórny początek, w kontekście stanu psychicznego, u pacjenta, który przez lata doświadczał przeżyć omamowo-urojeniowych o dużym nasileniu i lęku, prowadzących do kilku, poważnych w skutkach, prób samobójczych.

W dyskusji omówiono ponadto zagadnienie podwójnej diagnozy i kryteria psychozy indukowanej amfetaminą.

Czy schizofrenię można wyleczyć a jej objawy zresetować?

Słowa kluczowe: schizofrenia, psychoza indukowana amfetaminą, remisja

\section{Introduction}

The question put forward in the title of this paper originates from the father of the patient whose case is described. Based on the study of medical records, this is a story of a young person, repeatedly hospitalized with various diagnoses, among others drug-resistant schizophrenia, in whom psychiatric symptoms significantly decreased after waking up from coma, which was a consequence of an unfortunate accident in 2015.

The authors present the stages of treatment and subsequent hospitalizations of the patient, bearing in mind the question - is the re-start possible, in terms of mental state, with all its complexity, in a patient who for years experienced omental-delusive experiences of high intensity and anxiety, leading to several suicide attempts with serious consequences. An additional issue described in the discussion is the problem of a double diagnosis, which was faced by the doctors and clinicians involved in the therapy. Is it an amphetamine-induced psychosis or a classical schizophrenia, what is the difference between these two diseases? Is it possible to "reset" the human psyche, which will result in well-being or at least alleviat- ing psychotic symptoms, giving the chance for good social functioning?

\section{Case study - difficult beginnings, tragic finale and awakening ...}

The patient in question is now 31 years old, single, with gymnasium education, is the only child in the family, dependent on the family. Psychiatrically treated since 2002 with multiple diagnoses (borderline personality disorder, psychotic depression, bipolar disorder, addiction caused by taking some psychoactive substances, most recently schizophrenia). The beginning of mental health problems dates to the first grade of junior high school, i.e. from 1999. Then both of her grandmothers died. The grandmother on the mother's side had encephalomalacia (cerebral softening) and required constant care, therefore the patient's mother paid a lot of attention to her. The patient felt "alone" and until then she had been very much connected with her mother. Her junior high school class was disbanded because it was difficult in terms of educational level and created educational problems. From the beginning, the patient had a distorted self-image of "too 
big forehead", "bad eyes", she thought she was so "horrible" that she could not go to school. She said that when she would have money, she would do plastic surgery. She tried to take laxatives. He could not control herself - argumentative, destroying objects, smashed the glass in the door. The reasons for the patient's aggression were small things. After hospitalization in the Youth Department of the Psychiatry Clinic in August 2003 - she spoke to herself "in a stormy way", behaved impulsively, so that her parents feared her. She confirmed that she heard voices, although it was difficult to objectify these relations. She manipulated, blackmailed her parents, taking advantage of the fact that they were divorced, the patient's father was and still is supportive and resilient. She then took pernazine in a daily dose of $400 \mathrm{mg}$, after which an improvement was observed. After some time, the patient began to run away from home for the night, smoked cigarettes, probably marijuana. She also drank alcohol. She was accused of drug dealing. She got worse in school results. After such escapes, the police often brought her home. In high school, she tried amphetamine, probably after amphetamine she heard voices "from the park". She manifested self-destructive behaviors and attempted a suicide. She had two hospitalizations at the toxicological ward in February 2002 - intoxicatiomedicamentosasuicidalis (Codipar, Apap, Polopiryna S, Gripex); in May 2003 intoxicatiomedicamentosasuicidalis cum Luminal, Reasec, Pramolan, Claritine.

Since 2002, she has been repeatedly hospitalized - in the Youth Department of the Psychiatry Clinic, in the Neuropsychiatric Hospital in Lublin (2002-2008) and twice in the center of double diagnoses in Gliwice. She stopped her education at the level of first-class high school because of drugs - amphetamine, ecstasy, cocaine (because of a bad mental state). She did not report serious somatic diseases. She underwent asthma in childhood and concussion during primary school. She experienced commenting and imperative hallucinations. In 2003, head MR examination was performed. Brain tissue with the correct distribution of signal intensity, without focal changes. Ventricular system symmetrical, not expanded. Intravenous injection of the contrast agent did not reveal intracranial foci of pathological enhancement.

In October 2006, during a visit to the Mental Health Clinic, she confirmed that she heard voices, she had periods of increased anxiety. Then treated with olanzapine 10 mg, carbamazepine 300 mg,flupenticoxol. In February 2009 , she reported in the outpatient department an impression of omnipotence, ideas of reference and delusions of reference,derealization, but she was critical with the disease experience. The treatment was changed from aripiprazole to risperidone. She then was taking risperidone $4 \mathrm{mg} / \mathrm{d}$, clozapine $450 \mathrm{mg} / \mathrm{d}$, valproic acid 1500 mg / d. The she was referred for treatment to the Daily Department. In May 2009, the patient was diagnosed with symptoms typical of residual schizophrenia with the predominance of psychotic symptoms. The patient had significant features of drug resistance and severe side effects as a result of clozapine use. It was recommended to modify the therapy as part of the hospitalization in the Department of Psychiatry, where improvement in the symptoms of production was achieved. Zuclopentyksol $20 \mathrm{mg} /$ day, valproic acid $1500 \mathrm{mg} /$ day and levomepromazine 100 mg per night were recommended. After a month, there was a recurrence of productive symptoms, anxiety and withdrawal thoughts. The patient slept well but there was a problem of urinary incontinence. Amisulpride $400 \mathrm{mg}$ was included, it was recommended to add $10 \mathrm{mg}$ of zuclopenthixol at midday and use of alprazolam $0.5 \mathrm{mg}$ when needed.

In August 2009 there was a significant increase in auditory hallucinations of commenting voices type. She was afraid of them. She slept well, she did not feel drowsy during the day, which pleased her. The mood was balanced. The dose of amisulpride was increased to 1200 / day. In addition, she was taking $40 \mathrm{mg} /$ day zuclopenthixol, valproic acid at $100 \mathrm{mg} /$ day, levomepromazine-75 mg / day. In November 2011, the delusional and ideas of reference and delusions of reference symptoms intensified again. She received clozapine $200 \mathrm{mg} /$ day, flupenticol 6mg / day and lamotrigine 50mg / day. In 2012 she was treated with: clozapine $125 \mathrm{mg} /$ day, mianserin $90 \mathrm{mg} /$ day, trazodone $150 \mathrm{mg} /$ day, lamotrigine $100 \mathrm{mg}$ / day, valproic acid 600mg / day.

In 2015, the patient was admitted to the Intensive Care Unit of the Hospital Emergency Department in the severe general condition due to acute respiratory failure in the course of multi-organ trauma which she suffered as a result of injury and fall from height. At the Hospital Emergency Department, a wide cut wound of neck soft tissues and wounds within the face were managed. At the time of admission to the Intensive Care Unit, the patient was unconscious, intubated, artificially ventilated. Artificial ventilation of the lungs, sedation, were continued, circulatory system was supported by the infusion of catecholamines, wide-spectrum antibiotic therapy and nutritional treatment were implemented. Also anti-swelling and neuroprotective treatment of brain were applied. Artificial lung ventilation was continued for several days, and then the patient breathed spontaneously with passive oxygen therapy through the endotracheal tube. Percutaneous tracheostomy was performed under general anesthesia. The patient was unconscious, with no logical contact with the environment, despite the lack of infusion of sedatives, breathing independently with passive oxygen therapy through a tracheostomy tube, circulatory- 
efficient, fed by a nasogastric tube with the diagnosis of: acute respiratory failure, condition after surgical management of cut wounds of neck and face, lung contusion, brain contusion, cerebral edema, changes in the DAI CNS, subarachnoid hemorrhage, mediastinal hemorrhage, circulatory failure, left hip bone fracture, fracture of the transverse lumbar spine, paranoid schizophrenia, addiction to diazepam in the interview, was sent to the Department of Neurology for further treatment. There, posttraumatic axonal brain damage, post-traumatic subarachnoid hemorrhage, major quadriplegia at the right side, and multi-organ trauma after falling from height, paranoid schizophrenia, suspected suicide attempt, hyponatremia, were diagnosed. At the discharge from the Department of Neurology, the patient was conscious, without verbal contact, she followed the examiner's eyes, performed simple commands, had a quadriplegic paresis on the right side, plantar reflex present on both sides.

In July 2015, the patient was brought from the Care and Treatment Facility, where she probably experienced psychotic experiences (auditory hallucinations?). After waking up from a coma - she could give her name and the place correctly. The information obtained from the patient's mother revealed that after waking from a coma for 2 weeks her mental state deteriorated, the psychomotor agitation was present, she confirmed the presence of auditory hallucinations. The patient in clear consciousness in the partially impaired auto and allopsychic orientation, with impoverished facial expression. Her behavior indicated that she might have had psychotic experiences. Treatment with clozapine $75 \mathrm{mg}$ / day and olanzapine $10 \mathrm{mg}$ / day was applied, improving the mental state. The patient eagerly made verbal contact, followed instructions, slept at night. She consumed meals with assistance. She negated the presence of productive type symptoms, anxiety or depressed mood. There were also no suicidal thoughts. A rehabilitation physician was consulted. The patient was discharged and taken home in good condition, under the care of her mother.

In September 2016 there was a deterioration of her mental state - thoughts about death, about the murder of her father, compulsions and the compulsion to act. Diagnosis F20.0. The patient in a balanced mood and drive. Affection and facial expressions were pale. No persecutory delusions and auditory hallucinations. She negated the occurrence of thoughts against herself. Clozapine in a dose of $75 \mathrm{mg}$ / day was administered.

In January 2017, she reported to the Psychiatric Outpatient Clinic with her father. She tried to stop her being incapacitated. The father claimed that the patient did not show symptoms of the disease - schizophrenia, she successfully underwent the next stages of rehabilitation. She was mentally fit. She successfully dealt with matters in the bank and in the store, she functioned quite well. EEG and neuropsychological testing were recommended. The EEG record revealed small abnormalities over the anterior region of the brain on both sides, in the form of free theta waves. Basic activity preserved. The patient did not remember much from before the accident. In February 2016, she was treated in a neuropsychiatric hospital, where paranoid schizophrenia was diagnosed and other specific mental disorders caused by brain damage and dysfunction or somatic disease. During this period, the patient was after head injury (coma), had speech defects and sleep problems. Clozapine was replaced with chlorprothixene. She had a squeak in her head. She switched on the radio to quell her voices, confirmed that she "had schizophrenia, and additionally taking amphetamine" . Sertindol $4 \mathrm{mg}$ was included. At the end of February that year she reported to a visit with her father. She showed medical documentation. She said that in the Care and Therapy Facility she had awaken from a coma, did not know what was going on, did not know why she was in bed, why she was in a psychiatric ward, but it was a mistake, because she did not have hallucinations, sometimes she did not understand what she was spoken. She was treated with olanzapine $5 \mathrm{mg}$. The progress in rehabilitation was visible. Since 2006, she has not taken amphetamine and marijuana. Good self-esteem of current mental efficiency, she said "it was not true that the boyfriend urged to suicide", "the boyfriend saved me".

In February 2017 head MRI with diffusion was performed - with contrast. Clinically, posttraumatic axonal brain damage; post-traumatic subarachnoid haemorrhage. In the examination - on the right side in the temporal lobe, an irregular area with a fluid morphology of 18x9 $\mathrm{mm}$ - the evolution of post-traumatic changes. In addition, in the right temporal and parietal lobes of the corticosubcortical borderline, about 6-8 $\mathrm{mm}$ areas with elevated IS in the FLAIR sequence. A small area with a similar morphology in a radial glia on the right side and about 7-9 $\mathrm{mm}$ on both sides in the frontal-occipital region as well as a discrete area of the cortico-subcortical border region in the occipital region on the left. In addition, cerebral tissue with the correct distribution of signal intensity without focal changes. Symmetrical corpus callosum with correct signal morphology. The lateral brain ventricles were symmetrical, not dilated, not displaced. Within the intracranial structures, no pathologic reinforcement was observed after administration of paramagnetic contrast agent. There were no signs of increased intracranial pressure. In the MR picture, the morphology of the cerebrospinal meningeal signal was normal. Nasal sinuses normal.

In March 2017 there was a lawsuit. Expert witness further supported the desire of incapacitation. The patient demanded a change of treatment from olanzapine to perinase of $25 \mathrm{mg}$. 


\section{Discussion}

There is much evidence that patients with psychotic disorders are more susceptible to compulsive use of psychoactive substances including amphetamine derivatives. Adverse reactions associated with amphetamine use include anxiety, aggression, paranoia, hyperactivity, decreased appetite, tachycardia, increased respiration, mydriasis, increased blood pressure, tremors and arrhythmias. Observational studies confirm the relationship between amphetamine intake and the development of acute psychosis $[9,10]$. Early studies have shown that amphetamine can induce acute psychosis in previously healthy people. Psychoses induced by psychoactive substances were reported in 8-46\% of people regularly using amphetamine. Symptoms of amphetamine- induced psychosis are very similar to the symptoms occurring in psychoses from the spectrum of schizophrenia: attention deficit disorders, persecutory perception, increased physical activity, disorganized thinking, lack of insight, anxiety, suspiciousness, auditory hallucinations [2.4]. The distinction between amphetamine-induced psychosis and schizophrenia, especially at the beginning can be very difficult [3.5]. Since in the presented case study the diagnostic problem of amphetamine-induced schizophrenia / psychosis is mentioned, it is worth presenting the basic diagnostic criteria of drug-induced psychotic disorder according to DSM-5. They are:

A - the presence of one or both of symptoms such as delusions and hallucinations

B - medical history, physical examination or laboratory test results prove either the symptoms listed in criterion A that occurred during or shortly after substance poisoning or shortly after its discontinuation or the substance / drug has the potential to cause hallucinations and delusions.

C - disturbances cannot be better explained by the occurrence of a psychiatric disorder not induced by substance/drug.

D - the disturbance does not occur only in the course of delirium

E - the disturbance causes clinically significant distress or impairment in social, occupational or other important functioning sphere [1].

Some researchers suggest that visual hallucinations and omnipotency may be the differentiating elements . In amphetamine-induced psychoses, less marked are the thinking disorders characteristic of schizophrenia such as thinking confusion, abstract thinking disorders, goaloriented thinking disorders [8]. In contrast to schizophrenic psychoses, acute amphetamine-induced psychoses appear to subside faster and disappear during abstinence, although this remission may not be complete, whereby the precipitation of psychosis by amphetamine in healthy people may be blocked by antipsychotic drugs $[6,7]$.

This presented case of the patient can be summarized as follows: the patient hospitalized psychiatrically, treated for years on an outpatient basis, numerous diagnoses: a psychosis induced by psychoactive substances, borderline personality disorder, psychotic depression, paranoid schizophrenia, residual schizophrenia, with the characteristics of drug resistance, receiving antipsychotics in high doses, completely incapacitated, as a result of self harm and fall from height, which is probably another suicide attempt, she found herself in a coma, and after wakening and another psychiatric hospitalization she regained mental fitness - the severity of psychotic symptoms evidently decreased, the old omental-delusive experiences almost completely disappeared. Can post-traumatic changes mainly to the right temporal region be related with the reduction of psychotic symptoms? Recently, the patient takes a small dose of an antipsychotic drug, functions well, has partner support, plans a marriage. The patient strongly upheld that she had not used psychoactive drugs since 2006 (over 10 years). She admitted that she had different ideas about the use of antipsychotics, in the period before the suicide attempt with severe consequences, she discontinued medication, tried to cure on her own, looked for protein substances on the Internet. Her father confirmed that at that time, her psychotic experiences intensified, mainly auditory hallucinations, she talked with her voices. According to her father, after waking from a coma, the patient's condition changed significantly, hallucinations ceased, the daughter took steps for the rehabilitation of neurological disorders. In the course of writing this work, the authors received information from the family that the patient again stopped taking her small doses of antipsychotic medication, left the house at night, was stopped by the police, she was sent to a psychiatric hospital, she was admitted without consent. Haloperidol was started.

In this case, it turns out that the symptoms of schizophrenia, with all the abundance of psychopathology typical of this disease, can be overcome, restoring relative psychological wellbeing. Can schizophrenia be cured? Can its symptoms be reset? Schizophrenia may occur in various ways. Most often, its course is heaving - with periods of exacerbation and remission. Remissions can be complete and partial. It is less linear - successive exacerbations give less and less complete remissions. Of course, it is most beneficial if exacerbations are rare and full remissions occur. The answer to the above questions can therefore be affirmative when achieving complete remission can be regarded as resolving - taking into account the possibility of another episode and by accepting taking antipsychotic drugs during the remission period and as the reset of schizophrenia we consider a significant improvement in psychological well-being caused by the disappearance of psychotic symptoms. It seems, however, that recent events in the patient's life do not justify such optimism in this case. 


\section{Wstęp}

Pytanie stanowiące tytuł niniejszej pracy padło z ust ojca pacjentki, której przypadek został opisany.Jest to, oparta na studium dokumentacji medycznej,historia młodej osoby, wielokrotnie hospitalizowanej z różnymi rozpoznaniami m. in. schizofrenii lekoopornej, u której objawy psychiatryczne w sposób znaczący zmniejszyły się po wybudzeniu ze śpiączki, jaka była następstwem nieszczęśliwego wypadku w 2015 roku.

Autorzy pracy prezentują etapy leczenia i kolejne hospitalizacje pacjentki, mając na uwadze zapytanie - czy jest możliwy powtórny początek, w kontekście stanu psychicznego, przy całej jego złożoności, u pacjenta, który przez lata doświadczał przeżyć omamowo-urojeniowych, o dużym nasileniu, i lęku, prowadzących do kilku, poważnych w skutkach, prób samobójczych. Dodatkowym zagadnieniem omówionym $\mathrm{w}$ dyskusji jest problem podwójnej diagnozy, z którym zmagali się lekarze i klinicyści zaangażowani w terapię. Czy to psychoza indukowana amfetaminą czy klasyczna schizofrenia, co różni te dwie choroby? Czy jest możliwy „reset” psychiki ludzkiej, którego skutkiem będzie dobrostan a przynajmniej załagodzenie objawów psychotycznych, dające szansę na dobre funkcjonowanie społeczne?

\section{Opis przypadku - trudne początki, tragiczny finał i ... przebudzenie}

Omawiana pacjentka ma obecnie 31 lat,panna, wykształcenie gimnazjalne, jest jedynaczką, na utrzymaniu rodziny. Leczona psychiatrycznie od 2002 z wieloma rozpoznaniami (zaburzenie osobowości borderline, depresja psychotycza, CHAD, uzależnienie spowodowane przyjmowaniem kilku substancji psychoaktywnych, ostatnio schizofrenia).Początek problemów ze zdrowiem psychicznym od klasy pierwszej gimnazjum,tj. od roku 1999. Wówczas umarły obie babki pacjentki. Babka ze strony matki pacjentki miała malację mózgu i wymagała stałej opieki, dlatego matka poświęcała jej wiele uwagi. Pacjentka została „sama”, a dotychczas była bardzo związana z matką. Jej klasę w gimnazjum rozwiązano, ponieważ była trudna pod względem poziomu i stwarzała problemy wychowawcze. Pacjentka miała od początku zaburzony obraz siebie „za duże czoło”, „niedobre oczy”, uważała, że jest tak „potworna”, że nie może iść do szkoły. Mówiła, że jak będzie miała pieniądze, to zrobi sobie operację plastyczną. Próbowała brać leki przeczyszczające. Nie panowała nad sobą - kłótliwa, niszczyła przedmioty, wybiła szybę w drzwiach. Powodem agresji pacjentki bywały drobiazgi. Po hospitalizacji w Oddziale Młodzieżowym Kliniki Psychiatrii w sierpniu 2003 roku - mówiła do siebie „burzliwie”, zachowywała się impulsywnie, tak że rodzice bali się jej. Potwierdzała, że słyszy głosy, aczkolwiek trudno jest zobiektywizować te relacje. Manipu- lowała, szantażowała rodziców, wykorzystując przy tym fakt, że są oni rozwiedzeni, ojciec pacjentki był i jest nadal wspierający i ustępliwy. Przyjmowała wówczas pernazynę w dawce dobowej $400 \mathrm{mg}$, po której zaobserwowano poprawę. Po pewnym czasie pacjentka zaczęła uciekać z domu na noc, paliła papierosy, prawdopodobnie marihuanę. Piła też alkohol. Posądzono ją o dilerstwo narkotyków. Pogorszyła się w wynikach w szkole. Po takich ucieczkach z domu przyprowadzała ją często policja. W liceum próbowała amfetaminy, prawdopodobnie po amfetaminie słyszała głosy „z parku”. Przejawiała zachowania autodestrukcyjne, podejmowała próby samobójcze. Odbyła dwie hospitalizacje w oddziale toksykologicznym w lutym 2002 r.- intoxicatio medicamentosa suicidalis (Codipar, Apap, Polopiryna S, Gripex); oraz w maju 2003 r. - intoxicatio medicamentosa suicidalis cum Luminal, Reasec, Pramolan, Claritine.

Od 2002 roku hospitalizowana wielokrotnie psychiatrycznie - w Oddziale Młodzieżowym Kliniki Psychiatrii, w Szpitalu Neuropsychiatrycznym w Lublinie (20022008) i dwukrotnie w ośrodku podwójnych diagnoz w Gliwicach. Przerwała edukację na poziomie pierwszej klasy LO z powodu narkotyków - amfetamina, extasy, kokaina (w tle złego stanu psychicznego). Poważnych chorób somatycznych nie zgłaszała. Przeszła astmę w dzieciństwie i wstrząśnienie mózgu w okresie szkoły podstawowej. Doświadczała halucynacji komentujących a następnie imperatywnych. W 2003 roku wykonano badanie MR głowy. Tkanki mózgowia o prawidłowym rozkładzie intensywności sygnału, bez zmian ogniskowych. Układ komorowy symetryczny, nieposzerzony. Dożylna iniekcja środka kontrastowego nie ujawniła wewnątrzczaszkowych ognisk patologicznego wzmocnienia.

W październiku 2006 roku podczas wizyty w PZP potwierdzała, że słyszy głosy, miewała okresy wzmożonego niepokoju. Leczona wówczas olanzapiną $10 \mathrm{mg}$, karbamazepiną $300 \mathrm{mg}$, flupentyksolem. W lutym 2009 roku relacjonowała $w$ ambulatorium wrażenie owładnięcia, ksobności, derealizacji, ale była nastawiona krytycznie wobec przeżyć chorobowych. Zmieniono leczenie z arypiprazolu na risperydon.Przyjmowała wówczas risperydon $4 \mathrm{mg} / \mathrm{d}$, klozapinę 450mg/d, kwas walproinowy 1500 $\mathrm{mg} / \mathrm{d}$. Skierowana na leczenie do Oddziału Dziennego. W maju 2009 roku diagnozowano u pacjentki objawy typowe dla schizofrenii rezydualnej z przewagą objawów psychotycznych. Pacjentka o znacznych cechach lekooporności i nasilonych objawach ubocznych w wyniku stosowania klozapiny. Zalecono modyfikację terapii w ramach pobytu w Klinice Psychiatrii, gdzie uzyskano poprawę w zakresie objawów wytwórczych. Zalecono zuklopentyksol $20 \mathrm{mg} / \mathrm{d}$, kwas walproinowy $1500 \mathrm{mg} / \mathrm{d}$ oraz lewomepromazynę $100 \mathrm{mg}$ na noc. Po miesiącu miał miejsce nawrót objawów wytwórczych, lęku i myśli rezy- 
gnacyjnych. Pacjentka spała dobrze, ale pojawił się problem nietrzymania moczu. Włączono amisulpryd $400 \mathrm{mg}$, zalecono dołączenie $10 \mathrm{mg}$ zuklopentyksolu w południe a doraźnie stosowanie alprazolam 0,5 mg.

W sierpniu 2009 roku miało miejsce znaczne nasilenie halucynacji słuchowych o typie głosów komentujących. Chora odczuwała lęk przed nimi. Spała dobrze, nie odczuwała senności w ciągu dnia, co ją cieszyło. Nastrój miała wyrównany. Zwiększono do 1200/d dawkę amisulprydu. Poza tym przyjmowała $40 \mathrm{mg} / \mathrm{d}$ zuklopentyksolu, kwas walproinowy w dawce $100 \mathrm{mg} / \mathrm{d}$, lewomepromazynę $-75 \mathrm{mg} / \mathrm{d} . \mathrm{W}$ listopadzie 2011 roku nasiliły się ponownie objawy urojeniowe, ksobne. Przyjmowała klozapinę $200 \mathrm{mg} / \mathrm{d}$, flupentyksol $6 \mathrm{mg} / \mathrm{d}$ i lamotryginę $50 \mathrm{mg} / \mathrm{d}$. W 2012 roku w kwietniu leczona: klozapiną 125mg/d, mianseryną $90 \mathrm{mg} / \mathrm{d}$, trazodonem $150 \mathrm{mg} / \mathrm{d}$, lamotryginą $100 \mathrm{mg} / \mathrm{d}$, kwasem walproinowym 600mg/d.

W 2015 roku chora przyjęta do KIT z SOR w stanie ogólnym ciężkim z powodu ostrej niewydolności oddechowej w przebiegu urazu wielonarządowego, którego doznała w wyniku okaleczenia i upadku z wysokości. W ramach SOR zaopatrzono rozległą ranę ciętą tkanek miękkich szyi oraz rany w obrębie twarzy. W chwili przyjęcia do KIT chora nieprzytomna, zaintubowana, sztucznie wentylowana. Kontynuowano sztuczną wentylację płuc, sedację, układ krążenia wspomagano wlewem amin katecholowych, wdrożono szerokospektralną antybiotykoterapię i leczenie żywieniowe. Zastosowano także leczenie przeciwobrzękowe mózgu i neuroprotekcyjne. Sztuczną wentylację płuc kontynuowano kilka dni, a następnie chora oddychała spontanicznie $\mathrm{z}$ tlenoterapią bierną przez rurkę intubacyjną. Wykonano tracheostomię przezskórną w znieczuleniu ogólnym. Chora przytomną, bez logicznego kontaktu z otoczeniem, pomimo braku wlewu środków sedatywnych, oddychającą samodzielnie z tlenoterapią bierną przez rurkę tracheostomijną, wydolną krążeniowo, żywioną przez zgłębnik nosowo-żołądkowy z rozpoznaniem: ostra niewydolność oddechowa, stan po zaopatrzeniu chirurgicznym rany ciętej szyi i twarzy, stłuczenie płuc, stłuczenie mózgu, obrzęk mózgu, zmiany w OUN typu DAI, krwawienie podpajęczynówkowe, krwiak śródpiersia, niewydolność krążenia, złamanie trzonu kości biodrowej lewej, złamanie wyrostków poprzecznych odcinka lędźwiowego kręgosłupa, schizofrenia paranoidalna, uzależnienie od diazepamu $\mathrm{w}$ wywiadzie oddano do Kliniki Neurologii celem dalszego leczenia. Tam rozpoznano pourazowe aksonalne uszkodzenie mózgu, stan po pourazowym krwawieniu podpajęczynówkowym, niedowład czterokończynowy większy po stronie prawej, stan po urazie wielonarządowym w wyniku upadku z wysokości. Schizofrenia paranoidalna, podejrzene próby samobójczej, hiponatremia. Przy wypisie z Kliniki Neurologii pacjentka była przytomna, bez kon- taktu słownego, wodziła wzrokiem za badającym, spełniała proste polecenia, miała niedowład czterokończynowy większy po stronie prawej, obustronnie obecny objaw Babińskiego.

W lipcu 2015 roku pacjentka przywieziona z ZOL-u, gdzie prawdopodobnie podlegała przeżyciom psychotycznym (halucynacje słuchowe ?) Po wybudzeniu ze śpiączki- prawidłowo podawała imię i nazwisko oraz gdzie się znajduje. Z informacji uzyskanych od matki pacjentki wynikało, że po wybudzeniu ze śpiączki od 2 tyg. nastąpiło pogorszenie stanu psychicznego, pacjentka stała się pobudzona psychoruchowo, potwierdzała występowanie halucynacji słuchowych. Pacjentka w jasnej świadomości w częściowo zaburzonej orientacji auto i allopsychicznej, o mimice zubożałej. Z jej zachowania wynikało,że prawdopodobnie podlegała przeżyciom psychotycznym. Zastosowano leczenie klozapiną $75 \mathrm{mg} / \mathrm{d}$ i olanzapiną $10 \mathrm{mg} / \mathrm{d}$, uzyskano poprawę stanu psychicznego. Pacjentka chętnie nawiązywała kontakt słowny, spełniała polecenia, w nocy spała. Posiłki spożywała z pomocą. Negowała obecność objawów typu wytwórczego, lęk czy obniżony nastrój. Nie występowały też myśli samobójcze. Odbyła się konsultacja lekarza rehabilitacji. Pacjentka została wypisana i odwieziona do domu $\mathrm{w}$ dobrym stanie, pod opieką matki.

We wrześniu 2016 roku miało miejsce pogorszenie stanu psychicznego - myśli o śmierci, o zabójstwie ojca, kompulsje z przymusem działania. Rozp. F20.0. Pacjentka w wyrównanym nastroju i napędzie. Afekt i mimika były blade. Bez urojeń prześladowczych i halucynacji słuchowych. Zanegowała występowaniemyśli przeciwko sobie. Klozapina w dawce 75 mg/d.

W styczniu 2017 roku zgłosiła się do Poradni Psychiatrycznej z ojcem. Zabiegała o to, aby już nie stosować ubezwłasnowolnienia wobec niej. Ojciec twierdził, że pacjentka nie zdradzała objawów choroby - schizofrenii, przechodziła z powodzeniem kolejne etapy rehabilitacji. Była sprawna psychicznie. Załatwiała skutecznie sprawy w banku i w sklepie, dość dobrze funkcjonowała. Zalecono wykonanie EEG oraz badanie neuropsychologiczne. Zapis EEG o niewielkich cechach nieprawidłowych nad przednim obszarem mózgu obustronnie, w postaci powtrącanych nielicznie fal wolnych theta. Czynność podstawowa zachowana. Pacjentka niewiele pamiętała sprzed wypadku. W lutym 2016 roku leczona była w szpitalu neuropsychiatrycznym, gdzie rozpoznawano schizofrenię paranoidalną oraz inne określone zaburzenia psychiczne spowodowane uszkodzeniem i dysfunkcją mózgu lub chorobą somatyczną. W tym okresie pacjentka była po urazie głowy (śpiączka), miała wady mowy i kłopoty ze snem. Zamieniono klozapinę na chlorprothixen. Miała pisk w głowie. Włączała radio, żeby stłumić głosy, twierdziła, że „miała schizofrenię, a do tego doszła amfetamina”. Włą- 
czono sertindol 4mg. Pod koniec lutego br. zgłosiła się na wizytę z ojcem. Okazała dokumentację medyczną. Powiedziała, że w ZOL była wybudzona ze śpiączki, nie wiedziała co się dzieje, nie wiedziała czemu leży w łóżku, znalazła się w oddziale psychiatrycznym, ale to była pomyłka, bo nie miała halucynacji, czasem tylko nie rozumiała co mówi się do niej. Leczona olanzapiną $5 \mathrm{mg}$. Widoczne były postępy rehabilitacyjne. Od 2006 roku nie brała amfetaminy i marihuany. Dobra samoocena aktualnej sprawności psychicznej, mówiła „nieprawda,że chłopak namawiał do samobójstwa”, „chłopak mnie uratował”.

W lutym 2017 roku wykonano rezonans głowy z dyfuzja - z kontrastem. Klinicznie pourazowe aksonalne uszkodzenie mózgu; pourazowe krwawienie podpajęczynówkowe. W badaniu po prawej stronie w płacie skroniowym nieregularny obszar o morfologii płynu o wym. 18x9 mm - ewolucja zmian pourazowych. Ponadto w prawym płacie skroniowym i ciemieniowym pogranicza korowo-podkorowego ok. 6-8 mm obszary o podwyższonej IS w sekwencji FLAIR. Drobny obszar o podobnej morfologii $\mathrm{w}$ wieńcu promienistym po stronie prawejoraz około 7-9 mm obustronnie w okolicy czołowociemieniowej a także dyskretny obszar pogranicza korowo-podkorowego w okolicy potylicznej lewej. Poza tym tkanki mózgowia o prawidłowej dystrybucji intensywności sygnału bez zmian ogniskowych. Ciało modzelowate symetryczne o prawidłowej morfologii sygnału. Komory boczne mózgu symetryczne, nieposzerzone, nieprzemieszczone. W obrębie struktur wewnątrzczaszkowych nie stwierdza się ognisk patologicznego wzmocnienia po podaniu paramagnetycznego środka kontrastowego. Nie stwierdzono objawów wzmożonego ciśnienia śródczaszkowego. W obrazie MR morfologia sygnału opon mózgowo-rdzeniowych w granicach prawidłowych. Zatoki oboczne nosa prawidłowo powietrzne.

W marcu 2017 była sprawa sądowa. Biegły sądowy dalej podtrzymuje chęć ubezwłasnowolnienia. Pacjentka domaga się zmiany leczenia z olanzapiny na pernazynę $25 \mathrm{mg}$.

\section{Dyskusja}

Istnieje ogromna ilość dowodów na to, że pacjenci z zaburzeniami psychotycznymi są bardziej podatni na kompulsywne używanie substancji psychoaktywnych włączając pochodne amfetaminy. Objawy niepożądane związane ze stosowaniem amfetaminy to lęk, agresja, paranoja, nadaktywność, spadek łaknienia, tachykardia, wzrost częstości oddychania, rozszerzenie źrenic, wzrost ciśnienia krwi, drżenia i zaburzenia rytmu serca. Badania obserwacyjne potwierdzają związek między przyjmowaniem amfetaminy a rozwojem ostrej psychozy $[9,10]$. Już wczesne badania wykazały, że amfetamina może indukować ostrą psychozę u dotychczas zdrowych osób. Psychozy indukowane substancją psychoaktywną odnotowywa- no u 8-46 \% osób regularnie stosujących amfetaminę. Objawy psychozy indukowanej przez amfetaminę są bardzo podobne do objawów występujących w psychozach ze spektrum schizofrenii: zaburzenia koncentracji uwagi, urojenia prześladowcze, zwiększona aktywność ruchowa, dezorganizacja myślenia, brak wglądu, lęk, podejrzliwość, halucynacje słuchowe[2,4]. Rozróżnienie pomiędzy psychozą indukowaną amfetaminą a schizofrenią, zwłaszcza w początkach może być bardzo trudne [3,5].Ponieważ w przedstawionym studium przypadku przewija się problem diagnostyczny schizofrenia/ psychoza indukowana amfetaminą, warto $\mathrm{w}$ miejscu tym przytoczyć podstawowe kryteria diagnostyczne zaburzenia psychotycznego wywołanego substancją/lekiem zgodnie z DSM-5. Są nimi:

A - obecność jednego lub obu spośród objawów takich jak urojenia i omamy

B - wywiad, badanie fizykalne lub wyniki badań laboratoryjnych dowodzą albo o objawach wymienionych w kryterium A powstałych podczas lub wkrótce po zatruciu substancją lub wkrótce po jej odstawieniu albo wymieniona substancja/lek ma potencjał wywoływania omamów i urojeń.

C - zakłócenia nie można lepiej wyjaśnić występowaniem zaburzenia psychicznego niewywołanego substancją/lekiem.

D - zakłócenie nie występuje wyłącznie w przebiegu majaczenia

E - zakłócenie powoduje istotne klinicznie cierpienie lub upośledzenie w sferze społecznego, zawodowego lub innego ważnego funkcjonowania [1].

Niektórzy badacze sugerują, że elementem różniącym mogą być halucynacje wzrokowe i wielkościowość. W psychozach indukowanych amfetaminą mniej zaznaczone mogą być takie zaburzenia myślenia charakterystyczne dla schizofrenii jak rozkojarzenie myślenia, zaburzenia myślenia abstrakcyjnego, zaburzenia w zakresie myśłenia ukierunkowanego na cel[8]. W przeciwieństwie do psychoz schizofrenicznych ostre psychozy indukowane amfetaminą wydają się szybciej ustępować i zanikają w okresie abstynencji aczkolwiek remisja ta może nie być kompletna, przy czym precypitacja psychozy przez amfetaminę u osób zdrowych może być zablokowna przez leki przeciwpsychotyczne [6,7].

Omawiany przypadek pacjentki można streścić następująco: chora wielokrotnie hospitalizowana psychiatrycznie, leczona przez lata ambulatoryjnie, liczne rozpoznania: psychoza indukowana substancjami psychoaktywnymi, zaburzenie osobowości o typie borderline, depresja psychotyczna, schizofrenia paranoidalna, rezydualna, z cechami lekooporności, przyjmująca leki przeciwpsychotyczne w wysokich dawkach, ubezwłasnowolniona całkowicie, w wyniku okaleczenia i upadku z wysokości,będącego prawdopodobnie kolejną próbą samobójczą, 
znalazła się w śpiączce, a po wyjściu z niej i kolejnej hospitalizacji psychiatrycznej odzyskała sprawność psychiczną - nasilenie objawów psychotycznych widocznie się zmniejszyło, niemal całkowicie ustąpiły dawne przeżycia omamowo-urojeniowe. Czy zmiany pourazowe dotyczące głównie okolicy skroniowej prawej można łączyć z redukcją wytwórczych objawów psychotycznych? Ostatnio pacjentka przyjmuje małą dawkę leku przeciwpsychotycznego, funkcjonuje dobrze, ma wsparcie u partnera, planuje małżeństwo. Pacjentka stanowczo podtrzymywała, że od 2006 roku (ponad 10 lat) nie używała środków psychoaktywnych. Przyznawała, że miała różne pomysły co do stosowania leków przeciwpsychotycznych, w okresie przed próbą samobójczą z ciężkimi następstwami odstawiła leki, starała się leczyć na własną rękę, szukała substancji białkowych w internecie. Ojciec potwierdzał, że w tym czasie nasiliły się u niej przeżycia psychotyczne, głównie halucynacje słuchowe, rozmawiała z głosami. Zdaniem ojca, po wybudzeniu ze śpiączki stan pacjentki zmienił się znacznie, halucynacje ustały, córka podjęła działania zmierzające do rehabilitacji zaburzeń neurologicznych. W trakcie pisania tej pracy otrzymaliśmy informację od rodziny, że pacjentka ponownie odstawiła niewielkie dawki leku przeciwpsychotycznego, wyszła w nocy z domu, została zatrzymana przez policję, skierowano ją do szpitala psychiatrycznego, została przyjęta bez zgody. Rozpoczęto stosowanie haloperidolu.

W tym przypadku okazuje się, że objawy schizofrenii, z całym bogactwem psychopatologii typowej dla tej choroby, można pokonać, przywracając względny dobrostan psychiczny. Czy schizofrenię można wyleczyć? Czy jej objawy można zresetować? Schizofrenia może przebiegać w różny sposób. Najczęściej przebieg jej jest falujący - z okresami zaostrzeń i remisji. Remisje te mogą być całkowite i częściowe. Rzadziej przebiega liniowo - kolejne zaostrzenia dają coraz mniej pełne remisje. Najkorzystniej jest oczywiście wtedy, gdy zaostrzenia są rzadko, a remisje pełne. Odpowiedź na powyższe pytania może być więc twierdząca, gdy za wyleczenie uważa się osiągnięcie pełnej remisji - biorąc pod uwagę możliwość wystąpienia kolejnego epizodu i akceptując przyjmowanie w okresie remisji leków przeciwpsychotycznych a za reset schizofrenii uznamy znaczną poprawę dobrostanu psychicznego spowodowaną ustąpieniem objawów psychotycznych. Wydaje się jednak, że ostatnie wydarzenia z życia pacjentki nie uzasadniają w tym przypadku takiego optymizmu.

\section{Conflict of interest}

The authors have declared no conflict of interest.

\section{References:}

1. Diagnostic and Statistical Manual of Mental Disorders. Fifth Edition. DSM-5. American Psychiatric Publishing. Washington, DC, London, England, 2013.
2. Harri D., BatkiS.: Stimulant psychosis: symptom profile and acute clinical course. Am. J. Addict. 2000,9,1,28-37.

3. Srisurapanont M., Ali R., Marsden I., Suriga A., WadaK., Monteiro M.: Psychotic symptoms in methamphetamine psychotic in patients. Int. J. Neuropsychopharmacol. 2003, 6,4, 347-352.

4. Grace A.A.: Dopamine system dysregulationby the ventral subiculum as the common pathophisiological basis for schizophrenia psychosis, psychostimulant abuse and stress. Neurotox. Res., 2010,18, 3-4, 367-369.

5. Bramness at all. BMC Psychiatry, http/www.biomedcentral.com /1471-244x/12/221.

6. Medhus, S., Rognli, E. B., Gossop, M., Holm, B., Mørland, J., \& Bramness, J. G. (2015). Amphetamine-induced psychosis: Transition to schizophrenia and mortality in a small prospective sample. The American Journal on Addictions, 24(7), 586-589.

7. Talpos, J., Aerts, N., Waddell, J., \& Steckler, T. (2015). MK-801 and amphetamine result in dissociable profiles of cognitive impairment in a rodent paired associates learning task with relevance for schizophrenia. Psychopharmacology, 232(21-22), 3911-3920.

8. Niemi-Pynttäri, J. A., Sund, R., Putkonen, H., Vorma, H., Wahlbeck, K., \& Pirkola, S. P. (2013). Substance-induced psychoses converting into schizophrenia: a register-based study of 18,478 Finnish inpatient cases. The Journal of clinical psychiatry, 74(1), e94-9.

9. Selten, J. P., Booij, J., Buwalda, B., \& Meyer-Lindenberg, A. (2017). Biological Mechanisms Whereby Social Exclusion May Contribute to the Etiology of Psychosis: A Narrative Review. Schizophrenia bulletin, 43(2), 287-292.

10. Hsieh, J. H., Stein, D. J., \& Howells, F. M. (2014). The neurobiology of methamphetamine induced psychosis. Frontiers in human neuroscience, 8 .

\section{Correspondence address}

Ewelina Soroka

II Klinika Psychiatrii i Rehabilitacji Psychiatrycznej

Ul. Głuska 1, 20-439 Lublin

Email: dziwota.e@gmail.com

Otrzymano: 09.11.2016

Zrecenzowano: 05.12.2016,03.01.2017

Przyjęto do druku:01.12.2017 